\title{
The Concept of Love and The Basis of Its Doctrines Between Maqamat and Haal
}

\author{
Abdul Wachid B.S. \\ Universitas Islam Negeri (UIN) Prof. K.H. Saifuddin Zuhri \\ Jalan A. Yani 40-A Purwokerto, Jawa Tengah, Indonesia \\ abdulwachidbs33@gmail.com
}

Article History: Submitted on $6^{\text {th }}$ April 2021; Accepted on 25 ${ }^{\text {th }}$ May 2021;

Published on $30^{\text {th }}$ June 2021

\begin{abstract}
Sufism is the spiritual "path" of the Sufis to achieve eternal happiness. Sufism's orientation is a noble love for Allah SWT. Throughout the history of Sufism, love (isyq) for the Sufis became an ideology and a method of spiritual purification. Love restores the essence of human life to the Qur'an and Allah alone so that it has an essential accentuation of spirituality. This research uses a qualitative approach. This type of research is a library of research by collecting and documenting all the data relating to Sufism, love, and teachings, especially in the Qur'an and some Sufi figures. The results of this study revealed the love of a wayfarer (Salik) obtained through the long spiritual journey (suluk) in his life. It includes the prayer and the foundation of his stages (maqaamat), such as repentance (tawba), renunciation (zubd), patience (sabr), gratitude (syukr), and watchfulness (wara), and his basic doctrines such as fear (khauf) and hope (raja).
\end{abstract}

Keywords: sufism, love, stages (maqamat), haal.

\section{INTRODUCTION}

Sufism is the spiritual "path" of the Sufis to achieve eternal happiness. The sufis belong to the path of the Sunna and the moral value of Allah (Fuad, 2012; Hafiun, 2012). The realization of the spiritual "path" is "the attempts to achieve self-liberation through the true oneness of God", as Hans Heinrich Schaeder's statement (an orientalist) quoted by Annemarie Schimmel. These efforts have different shapes throughout the history of Sufism, but the essence remains the same: to achieve the absolute truth that "there is no god 
but Allah", and to build constantly self-consciousness that a servant just "prays and returns to Him." In other words, Sufism becomes a spiritual way to purify the self towards God (Farida, 2011).

The presence of Sufism is proof that Islam is a complete religion because it accommodates both inner and outer knowledge (ihsan) (Hermayanti, Purba, Lenggana, 2017). In the history of Sufism, mystics (Sufis) have several different ways to achieve their goal either individually or collectively, either through wisdom or through love, by isolating themselves or by practicing exercises. Its external history is the history of spiritual movements, theology, and literature in Islam. Moreover, because it comes from the ritual exercises taught by the Qur'an, Sufism reflects the various attitudes of the Muslims to the "world".

However, from the literature of Sufism, the "path" can be identified in two types; the first is Tariqa (Jalan-tarekat), and the second is the state or condition of a soul (Jalan-hal). Why do the Sufis focus more on "the path" (perhaps, the concept "path"is in line with the concept of "Laku" in Javanese terminology)? This is because the Sufis are more concerned about the noble moral, the attribute and the "deeds" (Laku) by following the Prophet SAW, his companions, and those after the Prophet SAW. This is because, according to al-Thusi (Al-Ataftazani, 1997), "The science of Sufis can be traced in the book of Allah SWT."

Many Sufic treatises mention that the Sufis, with their various schools, have a conception of Allah's path (tariqa). The path begins with spiritual practice. The Sufis gradually take various phases known as stages (maqamat) and state (abwal) and the peak of these phases are the knowing (ma'rifat) of God. The stages (maqamat) are the levels of a servant in the presence of God in the matter of worship and spiritual practices that he does. Meanwhile, the states (ahwal) are the clarity or purity of the soul seeing God in the recesses of the heart. According to al-Thusi (Al-Atafthazani, 1997), the states are not efforts through spiritual practices, not through stages (maqamat). The Sufis, according to Al-Qusyairi in his book al-Risalah al-Qusyairiyyah (AlAtaftazani, 1997), affirm that the stages (maqamat) are characterized by an establishment and pursued by the Sufis with the wills and efforts constantly. In the meantime, the states are precisely the conditions of the soul that change and vanish easily. They are accidentally acquired, so it was a kind of talent.

The next question is about the position of love between stages (maqamat) and the state (hal) in the perspective of Sufism? In his research on "Nilai-nilai Pendidikan Karakter Pada Ajaran Cinta dalam Tasawuf," Damis (2014) argues that love comes from 'azaliyya to eternity. Love is a gift from God, and only He has the right to be loved. According to Rabi'ah (2014), there are two kinds of love; love for myself and love for You.

Istiqomah (2020), in her research "Konsep Cinta Jalaluddin Rumi Perspektif Hermenentika," emphasized that the stage of love in Jalaluddin Rumi's view means totality and the embodiment of a servant's love for his 
beloved (God). When love is in the heart, the Divine light from within a servant emits. Therefore, love is also an integral part of Sufism. Jalaluddin Rumi is also the main subject in Marsudi's research (2017) "Tasawnf Jalaluddin Rumi Perspektif Annemarie Schimmel." According to him, love can always encourage humans to create distinctive symbols and meanings in life. Apart from being a Sufi, Rumi is also a poet who often writes the concept of love.

Ghazali (2013), in his research "Corak Tasawnf Al-Ghazali Dan Relevansinya Dalam Konteks Sekarang," explains the importance of love for life. According to al-Ghazali, in all states ( $h a l)$ and stages (maqamat) love must be the top priority and be love to all creatures of Allah. Therefore, whoever has love in his heart, Allah will love him.

The issue of love is also the main concern of Maharani (2017) in his book Filsafat Cinta. According to Maharani (2017), although it is invisible to the eye, love has a very strong impact on a lover. Love is a unique existence. Erich Fromm, a Western intellectual, also mentioned that love is a spiritual relationship between humans and God. However, there is a difference in the way data is collected. If Sufi uses a religious approach, the West represented by Fromm uses the experience of his neurotic patient. The explanation is in Aliffudin's research (2021) on "Konsep Cinta: Studi Komparasi Antara Pemikiran Jalaluddin Rumi dan Erich Fromm."

Some of the research results above show that love is the main intention of life. The presence of love is tantamount to the presence of God. Because of love, humans can produce symbols, and distinctive meaning of life and a substantive form of love is loving fellow creatures of Allah on earth.

This research will discuss the sources of the teachings of love, the stages, and the states. Mashar (2015) discussed the stages and the states in his research. Maqamat become stages of manners to Allah with various efforts through riyadah. The stages, in general, are repentance, renunciation, patience, gratitude, and satisfaction. Meanwhile, the states are fear, humility, sincerity, piety (taqwa), gratitude, and mutma'innah. Haifun (2017) confirmed Maqamat in Mashar's (2015) study. In Hafiun's research (2017), maqamat is the stages of getting to know Allah. These maqamat include repentance, watchfulness, renunciation, poverty, patience, gratitude, trust, and satisfaction.

The two studies have similarities in identifying the stages and the states. However, love has not been the object of the two studies. Jalaluddin Rumi and al-Ghazali considered love as the peak of stages. Therefore, the novelty of this research is the position of love between the stages and the states. It becomes the new formulation of stages in Sufism.

\section{METHOD}

This research uses a qualitative approach. Sugiyono (2007) states that a qualitative approach has artistic and artistic features. It is an interpretive approach because the research data is more related to data interpretation in 
the field and literature. It means that the object of study related to the interpretation of religious, cultural, artistic phenomena belongs to the qualitative domain.

It is library research. The researcher gets library data from books, articles, or the naqli arguments related to Sufism (love, maqom, hal) to identify the basics of its teachings. Then, the researcher obtains the data through the documentation method by reading, analyzing, and parsing information about the study through the available literature data.

The results of this documentation and reading function for several things; for documenting and conducting traveling theories about the stages, the states, and love based on the thoughts of al-Ghazali, Jalaluddin Rumi, alQushairi, and Hamka. In addition, the researcher used the naqli argument as a database such as; Q.S. adz-Dzaariyat, Q.S. al-Hajj, Q.S. al-Baqarah, Q.S. an-Nisa, Q.S. Ibrahim, and Q.S. al-Maaidah.

Data analysis focuses on the description, clarification, and placement of data in the context using argumentation (Faisal, 2010) to reveal the meaning behind the text (Ratna, 2011). The argument in this data analysis is based on traveling theory, tracing data through scientific journals, books, and research reports that discuss the issue of love in the Sufism tradition.

In this study, the researcher analyzed the concept of love by identifying the Sufism thoughts concerning al-Ghazali, Rumi, al-Qushairi, and Hamka. Furthermore, the researcher contextualized these Sufism thoughts with several previous studies and the verses of the Koran as the basis for explaining the concept of love.

\section{FINDINGS AND DISCUSSION}

\section{The Stages (Maqamat) And The States(Ahwa)}

The Sufis never agree on the number and order of the stages (maqamat). Harun Nasution quoted some of the views on the stages (maqamat), according to Abu Bakr Muhammad al-Kalabi', repentance - renunciation- patience - poverty - humility - piety - full dependence and belief in God - satisfaction - love - the knowledge of God. Abu Nasr al-Sarraj al-Tusi mentioned the order of the stages (maqamat) in al-Luma', ie, repentance - watchfulness - renunciation - poverty patience - full dependence and belief in God - the satisfaction of the heart. Abu Hamid al-Ghazali in Ibya Ulum al-Din mentioned the order of the stages (maqamat), ie, repentance - patience - poverty renunciation - full dependence and belief in God - love - the knowledge of God. According to Abu al-Qasim 'Abd al-Karim alQusyairi, the maqamat includes repentance - watchfulness renunciation - full dependence and belief in God - patience satisfaction. However, the usual order of the stages (maqamat) is 
repentance - renunciation - patience - full dependence and belief in God - satisfaction. After the maqamat, there are still states of the soul that are love - the knowledge of God - annihilation permanency - union (with God). Such union, according to Harun Nasution, may be referred to as al-bulul or wahdat al-wujud (Nasution, 1990).

In addition, examples of the states mentioned by Harun Nasution are fear, humility, obedience, sincerity, friendship, happiness, and gratitude. In addition, one mentions the states (hal) as watching (muraqabah), nearness (qarb), love, fear, hope, longing, intimacy (uns), tranquility, witnessing (musyahadah), certainty, etc ( Nasution, 1990).

All stages and states are the objects of Sufism based on the Qur'an. The verses of the Qur'an which are used as the basis of Sufism by Sufis are as follows.

The first to be called is prayer (doa) because prayer is the soul of worship, the whole expression of human relationships, both with human beings and with God directly, is the embodiment of prayer: " And I (Allah) did not create the jinns and humans except they should worship Me (Alone) (QS, al-Dzariyaat, 51:56). Worship with prayer as its principle brings human beings to the level of piety to Allah SWT: "O mankind, worship your Lord, who created you and those before you, that you may become righteous" (Q.S., al-Baqarah, 2:21). By such piety, a man makes himself a slave ('abid) and will obtain the contentment of Allah SWT: "The flesh of them shall not reach God, neither their blood, but godliness from you shall reach Him" (QS, Hajj, 22:37).

The bases of stages (maqamat) are as follows. In the teachings of Sufism, repentance is the first stage because sin becomes the veil between man and his God, then people who seek the contentment of Allah must repent first. "Truly, God loves those who repent, and He loves those who cleanse themselves" (Q.S., al-Baqarah, 2: 222).

Before becoming a Sufi, one must be a Zahid who leads a life of renunciation (asceticism), ie reject the luxury of world life and draw closer to Allah SWT. " "So as for he who transgressed and preferred the life of the world, then indeed, Hellfire will be [his] refuge" (QS. An-Naziaat: 37-39). "But as for he who feared the position of his Lord and prevented the soul from [unlawful] inclination, then indeed, Paradise will be [his] refuge" (QS. AnNaziaat: 40-41).

By living the ascetic life, a Sufi must be patient, and patience is essential to the Sufi life, every believing Muslim must own even it. "Allah is with those who are patient" (Q.S., al-Baqarah, 2: 153). 
Meanwhile, gratitude complements the patient. The essence of gratitude is the recognition of the gifts from Allah with full submission. Rabi'ah al-Adawiyah, the greatest female Sufi-poet, equated gratitude for misery with gratitude for prosperity. "And [remember] when your Lord proclaimed, 'If you are grateful, I will surely increase you [in favor]; but if you deny, indeed, My punishment is severe" (Q.S., Ibrahim, 14: 7).

Watchfulness (wara) is an important part of ascetic life. Watchfulness is to abstain from all things that are not good, and in the sense of Sufism is to leave all dubious (subhat).

All efforts passed through the stages (maqamat) are only to seek the contentment of Allah SWT because with His contentment, then the relationship between servant and his God became very close, and this is what is sought in the path of Sufism. "Allah being pleased with them and they with Him" (Q.S., al-Bayyinah, 98: 8).

The bases of states (ahwal) in the Qur'an are as follows.

In the teachings of Sufism, the fear (khauf) and the hope $\left(\right.$ raja $\left.^{\prime}\right)$ is the main and oldest teaching in Sufi life. Fear (khauf) is the fear of Allah and His punishment, while, the hope ( $\left.\mathrm{raja}^{\prime}\right)$ is expecting the contentment of Allah SWT and His heaven. " they pray to their Lord with fear and hope" (Q.S., as-Sajadah, 32:16). the fear and the hope are components of faith because the purpose is the hereafter.

The component that subsequently emerges from the ascetic life was longing and sadness. A person who loves a beloved will have a longing and sad if he wants to meet her. Moreover, the beloved is the Bost Beloved, Allah SWT. The longing is experienced by remembering (dhikr) the Beloved constantly: "O you who have believed, remember Allah with much remembrance" (Q.S., al-Ahzab, 33:41).

The level of love (mababbab) is based on the following verse, "For Allah is All-Sufficient, whereas it is you who need Him" (Q.S., Muhammad, 47:38). The reciprocal love between the servant and the Lord is stated in this verse, "Believers! If any of you should ever turn away from your faith, remember that Allah will raise up a people whom He loves, and who love Him ( QS, al-Maa'idah, 5:54).

Furthermore, knowing God (ma'rifat) is also a high level, often debated by Sufis, whether love is higher than ma'rifat, or vice versa. Knowing God (ma'rifat) is pursued by piety, noble behavior, and inspiration (ilham), and it is the basis of the ma'rifat, "Beware of the wrath of Allah. He teaches you the Right Way and has full knowledge of everything" (Q.S., al-Baqarah, 2: 282).

The love and knowing God (ma'rifat) are also often debated 
whether they are the stages (maqamat) or the states (ahwal). However, many Sufis include love and knowing God (ma'rifat) in both, the stages (maqamat) and the states (abwal).

The explanation above shows that Sufism is based on the Qur'an, concerning human morality and behavior at the stages (maqamat) and the states (abwal) of the Sufis. It will be too long if the researcher must explain all of the things revealed by the Sufi because all the references are taken from the Qur'an.

\section{The Concept Of Love And The Basis Of Its Doctrines Between Maqamat And Haal}

Love (hubb) is one of the main themes in the Sufi world. Discourses about love are often associated and understood as the stages of Sufi (maqamat), the state of soul (baal), and the reason for the existence of the cosmos (Suwito, 2013). The love (mahabab) belongs to two categories, it is categorized as a stage (maqam) and also a state ( $h a l)$. Love is categorized as a stage because there is a human effort as a servant to "remember" his God constantly. Love is categorized as a state because it can reveal the veil between servant and God as His will and grace. Because of love, in the stages (maqamat), Allah prevents a servant from being inclined to other than Him and gives guidance as a lover of God. Because of love, in states (ahwal), God becomes "Beloved" as an appearance of love.

The meaning of "love", in Kamus Besar Babasa Indonesia (Departemen Pendidikan dan Kebudayaan RI, 1989), is very happy (suka sekali), very dear (sayang benar), lovest, very eager (ingin sekah), hoping very much (berbarap sekali), or worry. Meanwhile, in Kamus Psikologi (1988: 263) a translation from The Penguin Dictionary of Psychology, love is a special feeling that concerns the pleasure of an object; love has emotional nuance if it comes to mind. It can awaken the whole primary emotion according to the emotion where the object is located.

The word love in this context is interpreted as bubb or mababbah in Arabic (Asfari MS and Soekatno Cr, 2002). Meanwhile, according to Al-Qushairi, love in the Sufi domain (Sufism) means mercy, turmoil, and care (Kaltsum, 2017). Compare with Jazil, et al., (Jazil and Musbikin, 2000) who collect some opinions about love (bubb or mababbah) as follows.

a. The word love (Cinta) (bubb/mababbab) which comes from the words habba-bubban-bibban and means waddabu, means affection; 
b. The word Hubb which comes from the word habab al-maa means the flood;

c. Love is called mababbah because it is the greatest form of concern for the heart;

d. Love is also often thought to come from the word $h a b b$ (grains) which is the plural form of habbat, and habbat al-qalb is something that sustains it. Thus, love is called bubb because it is stored in the heart;

e. Some say that the word bubb comes from the word bibbah, which means grain in the desert. Love called bubb because it is the basis of life, as bubb which is a seed of plants;

f. However, some say that love comes from the word hibb, ie the place in which there is water, and when it is full, there is no place for others. Likewise, with the heart, when it is filled with love, there is no place in the heart but for the Beloved.

Love (mababbah) has an important position because the journey of Sufism starts with upholding the oneness of God in the self by living an ascetic life (zubud). Zubud is able to grow the seeds of love, and because of the love Sufism is lived with sincerity.

The basis of the teachings concerning love comes from the Qur'an itself. The basis of all Muslim beliefs, sayings, and deeds is none other than the "opening verse", namely " In the name of God, the Most Gracious, the Most Merciful" (bismillaabirrabmaannirrabiimi).

In addition to the opening verse, many other verses more specifically contain the word love, for example, "kataba rabbukum 'ala nafsibirrabmah" (Your Lord has made mercy incumbent upon Himself); or the verse "innaLlaha yubibbul muttaqin" (Truly Allah loves the God-fearing); and this verse, "innaLlaha yubibbut tammbina wa yuhibbul mutathabbirina" (Truly, Allah loves those who abstain from evil and keep themselves pure).

The maximum confidence, statement, and act of love from someone are aimed at only one person, the person he loves most. Likewise, the relationship between a servant and his Lord will surpass profane love that is why the profane love in any life that has been enlightened by divine love will be ensouled by him so that the love of all love is always associated with the true meanings of love. The bases of Sufism concerning love nothing else derives from the Qur'an as follows. 
a. Say: Ifyour fathers, your sons, your brothers, your wives, your clan, your possessions that you have gained, commerce you fear may slacken, dwellings you love - if these are dearer to you than God and His Messenger, and to struggle in His way, then wait till God brings His command; God guides not the people of the ungodly'(Q.S., at-Taubah, 9:24);

b. Yet there be men who take to themselves compeers apart from God, loving them as God is loved; but those that believe love God more ardently. O if the evildoers might see, when they see the chastisement, that the power altogether belongs to God, and that God is terrible in chastisement'(Q.S., al-Baqarah, 2:165);

c. Say, [O Mubammad], "Ifyou should love Allah, then follow me, [so] Allah will love you and forgive you your sins. And Allah is Forgiving and Merciful."Say, "Obey Allah and the Messenger." But if they turn away - then indeed, Allah does not like the disbelievers" (Q.S., Ali Imran, 3:31-32);

d. O you who have believed, whoever of you should revert from his religion Allah will bring forth [in place of them] a people He will love and who will love Him [who are] bumble toward the believers, powerful against the disbelievers; they strive in the cause of Allah and do not fear the blame of a critic. That is the favor of Allah; He bestows it upon whom He wills. And Allah is all-Encompassing and Knowing” (Q.S., alMaaidah, 5:54).

Meanwhile, the love in Sufism also comes from the Sunnah of the Prophet SAW (Asfari MS and Soekatno Cr, 2002) as follows.

a. "My slave continues to draw closer to Me by doing naafil (supererogatory) deeds until I love him, and if I love bim I will be his hearing with which he hears, his vision with which he sees, his hand with which he strikes and his foot with which he walks. If he were to ask of $M e$, I would surely give to him; if he were to seek refuge with $M e$, I would surely grant bim refuge" (H.R., al-Bukhari);

b. "Love Allah for His countless bounties upon you and love me because you love Allah, and love my Able Bayt because of your love for me." (H.R., al-Tirmid₹i)

c. "There are three qualities which will make whoever has them taste the sweetness of faith (iman): to love Allah and His Messenger more than anyone else; to love a servant (of Allab) only for (the sake of) Allab; and 
to abhor returning to disbelief after having been saved from it by Allah as one would abhor being thrown into the fire." (H.R., al-Bukhari);

d. "Whoever loves to meet Allah, Allah will love to meet him, and whoever hates to meet Allaah, Allaab will hate to meet him." (H.R., al-Bukhari);

e. "Whoever possesses three qualities shall be forbidden to Hell-Fire and Hell-Fire is forbidden to bim: Belief in Allah, loving Allah, and to be thrown in Hell-Fire and be burnt is more beloved to him than going back to disbelief" (H.R., Ahmad Ibn Hambal);

f. 'David would supplicate, saying: O Allah, I ask you for your love and the love of those who love you and the deeds that will bring me your love. O Allah, make your love more beloved to me than myself and my family and even cold water." (H.R., al-Tirmidiri).

"The love does not expect rewards because love itself is a reward," Hamka said (Hamka, 1984). Therefore, the expression of love is also in line with one's faith, which is multilevel. Some who love God is caused by the fear of His threats, so that it causes a stage fear of Allah (khauf). Some who love God are caused by an endless hope for His heavenly promises so that it raises a stage of hope $\left(r^{\prime} a^{\prime}\right)$. However, there is a higher level that is the religious experience of loving Allah caused by love (al-hubb or mahabbah) itself, this is the stage developed by the greatest female Sufi-poet Rabiah alAdawiyah, also later by Jalaluddin Rumi.

Because of great love for God, all appearances of the universe are seen as entities containing the existence of Allah (wabdat al-wujud, Arabic; manunggaling kawula Gusti, Javanese). In this context, some interpreted that the teaching is precisely the affirmation of the oneness of Allah (wabdat al-wujud mumwahid) above all His creations, that "There is no me but Him (La ana illa Huwa)". This teaching was developed by Ibn Arabi and Hamzah Fansuri (in Barus, Aceh), who follow Ibn Arabi's views. The teaching was also asserted by al-Hallaj in Baghdad and Shaykh Siti Jenar in Java. In this case, the assessment of the teaching is still debated, whether it confirms the oneness of God or not (misleads). However, in the end, there is an abnormal development concerning the concept of wabdat al-wujud such as polytheism or syirk. Everything is seen and positioned as God.

\section{CONCLUSION}

From the discussion above, we can conclude that the love of a wayfarer (Salik) is obtained through a long effort or the long spiritual journey (Suluk) in his life. First is the prayer and its basic stages are repentance, 
zuhud, patience, gratitude, and watchfulness. Meanwhile, its basic states are fear (khauf) and hope (raja). In Sufism, fear (khauf) and hope (raja) are the main and oldest teachings in the Sufi life. Khauf is fear of Allah and His punishment, while hope ( $r a j a)$ is expecting the pleasure of Allah and His Heaven. The fear and the hope are components of faith because the goal is hereafter.

Whereas love (isyqun or mahabbab) belongs to two categories, it is a stage (maqam), and also a state (hal). Love is a stage (maqam) because human efforts as servants continuously remember their Lord. Love is a state ( $h a$ l) because it can open the veil between servants and God as God's will and gift.

\section{REFERENCES}

Al-Qur'an dan Terjemahannya. 1983/1984. Jakarta: Proyek Pengadaan Kitab Suci Al-Qur'an Departemen Agama RI.

Al-Ataftazani, A. al-W. al-G. (1997). Sufi dari Zaman ke Zaman. Bandung: Penerbit Pustaka.

Aliffudin, Andi Wahyu. (2021). "Konsep Cinta: Studi Komparasi Antara Pemikiran Jalaluddin Rumi dan Erich Fromm". Laporan Penelitian. Surabaya: Program Studi Tasawuf dan Psikoterapi Fakultas Ushuluddin dan Filsafat Universitas Islam Negeri Sunan Ampel Surabaya.

Asfari MS dan Otto Soekatno Cr. (2002). Mahabbah Cinta Rabi'ah al-Adawiyah. Yogyakarta: Bentang.

Damis, Rahmi. (2014) "Nilai-Nilai Pendidikan Karakter Pada Ajaran Cinta Dalam Tasawuf". Al-Ulum, Vol. 14, No. 1, Juni 2014. 127-152.

Departemen Pendidikan dan Kebudayaan RI. (1989). Kamus Besar Bahasa Indonesia. Jakarta: Departemen Pendidikan dan Kebudayaan RI.

Faisal, S. (2010). Format-format Penelitian Sosial. Jakarta: Raja Grafindo Persada.

Farida, M. (2011). Perkembangan Pemikiran Tasawuf dan Implementasinya di Era Modern. Substantia: Jurnal Ilmu-Ilmu Ushuluddin, 13(1), 105-114.

Fuad, J. (2012). Pendidikan Karakter Dalam Pesantren Tasawuf. Tribakti: Jurnal Pemikiran Islam, 23(1), 60-76.

Ghazali, Abd. Moqsith. (2013). "Corak Tasawuf Al-Ghazali Dan Relevansinya Dalam Konteks Sekarang". Al-Tahrir, Vol. 13, No. 1, Mei 2013. 61-85.

Hafiun, M. (2012). Teori Asal Usul Tasawuf. Jurnal Dakwah Media Komunikasi Dan Dakwah, 13(2), 241-253. https://doi.org/https://doi.org/10.14421/jd.2012.13206 . (2017). "Zuhud Dalam Ajaran Tasawuf". Hisbab: Jurnal Bimbingan Konseling dan Dakwah Islam, Vol. 14, No. 1, Juni 2017. 77-93.

Hamka. (1984). Tasawnf Perkembangan dan Pemurniannya. Jakarta: Pustaka Panjimas.

Hermayanti, Pungky, Purba, Arif Budimansyah, Lenggana, U. T. (2017). Implementasi Metode Scoring System Sebagai Parameter dalam Memahami Kajian Ilmu Tasawuf Berbasis Android. Jurnal Online 
Informatika, 2(2), 92-101. https://doi.org/10.15575/join.v2i2.110

Istiqomah, Clara Indria. (2020). "Konsep Cinta Jalaluddin Rumi Perspektif Hermeneutika". Tesis. Malang: Program Studi Ilmu Agama Islam Pascasarjana Universitas Negeri Malang.

Jazil, Saiful., Imam Musbikin, S. (2000). Senandung Cinta Jalaluddin Rumi. Yogyakarta: Pustaka Pelajar.

Kaltsum, L. U. (2017). Ayat Cinta dalam Tafsir Sufi (Analisis Kata Hubb dalam Tafsir Dzu al-Nun al-Misri). Al-Itqan; Jurnal Studi Al-Qur'an, 3(1), 44-59.

Maharani, Sabrina. (2017). Filsafat Cinta. Jogjakarta: Garasi.

Marsudi, M. Maulana. (2017). "Tasawuf Jalaluddin Rumi Perspektif Annemarie Schimmel". Jurnal al-Hikmah, Vol. 03, No. 1, Januari 2017.

Mashar, Aly. (2015). Taswuf: Sejarah, Madzhab, dan Inti Ajarannya". AlA'raf: Jurnal Pemikiran Islam dan Filsafat, Vol. XII, No. 1, Januari-Juni 2015. 97-117. ISSN: 1693-9867.

Nasution, H. (1990). Filsafat dan Mistisisme dalam Islam. Jakarta: Bulan Bintang.

Ratna, N. K. (2011). Teori, Metode, dan Teknik Penelitian Sastra: dari Strukturalisme hingga Poststrukturalisme Perspektif Wacana Naratif. Yogyakarta: Pustaka Pelajar.

Sugiyono. (2007). Metode Penelitian Kuantitatif, Kualitatif dan R\&D. Bandung: Alfabeta.

Suwito. (2013). Relasi Cinta dalam Tasawuf. Teologia, 25(2). 